\title{
PENGARUH KOMPETENSI DAN MOTIVASI PADA PENYERAPAN ANGGARAN BELANJA MODAL DENGAN KOMITMEN ORGANISASI PEJABAT PENGELOLA KEUANGAN SEBAGAI VARIABEL PEMODERASI
}

\author{
Egidius Imanuel Laka ${ }^{1}$ \\ I Made Sukartha ${ }^{2}$ \\ Dewa Gede Wirama ${ }^{3}$ \\ ${ }^{1,2,3}$ Fakultas Ekonomi dan Bisnis Universitas Udayana, Indonesia \\ Email: Egidiuslaka82@gmail.com
}

\begin{abstract}
ABSTRAK
Tujuan penelitian ini adalah untuk menguji pengaruh kompetensi dan motivasi pejabat pengelola keuangan pada kinerja penyerapan anggaran belanja modal di pemerintah daerah Kabupaten Timor Tengah Utara dengan komitmen organisasi sebagai pemoderasi. Sebanyak 31 Organisasi Perangkat Daerah (OPD) di lingkungan pemerintah daerah Kabupaten Timor Tengah Utara merupakan sampel yang diambil dari keseluruhan populasi dalam penelitian ini. Pengambilan sampel dari keseluruhan populasi dikenal dengan teknik sampel jenuh atau sensus. Jumlah responden sebanyak 93 responden. Semua jawaban responden terhadap pernyataan penelitian menggunakan kuesioner merupakan data primer yang digunakan dalam penelitian ini. Pengujian hipotesis dilakukan dengan regresi berganda dan regresi moderasi (MRA). Kompetensi dan motivasi pejabat pengelola keuangan terbukti berpengaruh positif pada kinerja penyerapan anggaran belanja modal berdasarkan hasil uji data yang dilakukan. Disisi lain pengaruh kompetensi dan motivasi pada penyerapan anggaran belanja modal tidak mampu diperkuat oleh komitmen organisasi.
\end{abstract}

Kata kunci: Kompetensi, motivasi, komitmen organisasi, belanja modal

\begin{abstract}
The purpose of this study is to examine the influence of competence and motivation of financial management officials on the performance of capital expenditure absorption in local government of Timor Tengah Utara with organizational commitment as moderating variable. The population in this study is the work units (OPD) in Timor Tengah Utara regency government environment as much as 31 OPD. Sampling of the entire population is known by the technique of saturated samples or censuses. The number of respondents was 93 respondents. All respondents' answers to the research statement using questionnaires are the primary data used in this study. Hypothesis testing was done by multiple regression and moderation regression (MRA) Data used in the form of primary data using questionnaires. The analysis technique used are multiple regression and moderated analysis regression (MRA). The result of multiple regression analysis shows that competence and motivation of financial management officials proved have a positive effect on the performance of capital expenditure absorption, and moderated regression analysis shows that organizational commitment had no strengthen the influence of competence and motivation on capital expenditure absorption.
\end{abstract}

Keywords: Competence, motivation, organizational commitment, capital expenditure 


\section{PENDAHULUAN}

Desentralisasi yang dilakukan dengan pemberian kewenangan penuh dari pemerintah pusat kepada pemerintah daerah merupakan salah satu cara yang ditempuh oleh pemerintah Indonesia dalam rangka menyeimbangkan pengelolaan keuangan antara pemerintah pusat dan daerah demi pemerataan pembangunan. Selain itu desentralisasi yang dilakukan bertujuan agar sistem pengelolaan keuangan bisa berjalan secara demokratis adil dan proporsional yang tentunya berdasarkan pada keadaan dan potensi dari daerah masing-masing yang ada di Indonesia. Pelaksanaan dan penetapan sistem desentralisasimenyebabkan pengelolaan anggaran daerah dialokasikan dan diserahkan sepenuhnya kepada daerah otonom (Undang-Undang No 33 Tahun 2004).

Kenyataan yang terjadi di daerah baik itu provinsi dan kabupaten, penyerapan anggaran selalu tidak mencapai target sepertiyang ditetapkan dalam anggaran pendapatan dan belanda daerah (APBD). Berdasarkan evaluasi yang dilakukan oleh Direktorat Jenderal (Dirjen) Bina Keuangan Daerah Kementrian Dalam Negeri pada triwulan dua atau semester satu tahun 2015, realisasi anggaran untuk APBD masingmasing provinsi rata-rata hanya 27,40 persen, seharusnya pada semester satu atau triwulan dua setiap tahun anggaran, penyerapan anggaran sudah mencapai lima puluh persen. Tabel 1.1 menunjukkan bahwa tingkat penyerapan anggaran semua provinsi di Indonesia tidak mencapai 50 persen pada akhir triwulan dua atau semester I. Provinsi dengan tingkat penyerapan anggaran tertinggi adalah Provinsi Jambi yang mencapai 48,63 persen dan Provinsi Riau adalah provinsi yang paling rendah tingkat 
penyerapan anggarannya yaitu hanya sebesar 13,21 persen. Ada empat provinsi yang tercatat memiliki tingkat penyerapan anggaran di bawah 20 persen yaitu Maluku Utara 19,47, DKI Jakarta 19,23, Kalimantan Utara 16,39 dan Jambi sebesar 13,21 persen.

Tabel 1.1.

Data Penyerapan Anggaran APBD Semester I Provinsi Se-Indonesia Tahun 2015

\begin{tabular}{clcclc}
\hline No & \multicolumn{1}{c}{ Provinsi } & $\%$ & No & \multicolumn{1}{c}{ Provinsi } & $\%$ \\
\hline 1 & Jambi & 48,63 & 18 & Kalimantan Timur & 30,38 \\
2 & Kalimantan Tengah & 45,33 & 19 & Sumatera Barat & 28,95
\end{tabular}




\begin{tabular}{clllll}
3 & Kepulauan Riau & 38,89 & 20 & Papua Barat & 28,86 \\
4 & Jawa Timur & 38,34 & 21 & Bengkulu & 28,13 \\
5 & Jawa Tengah & 37,96 & 22 & Bali & 27,85 \\
6 & Kalimantan Selatan & 37,54 & 23 & Sulawesi Barat & 27,70 \\
7 & Gorontalo & 37,31 & 24 & Kepulauan Babel & 27,43 \\
8 & NTB & 37,00 & 25 & Sumatera Utara & 27,31 \\
9 & Sulawesi Utara & 36,61 & 26 & Banten & 26,29 \\
10 & NTT & 36,55 & 27 & Sumatera Selatan & 25,65 \\
11 & Sulawesi Tenggara & 34,03 & 28 & Nangroe Aceh Darusalam & 23,32 \\
12 & Sulawesi Selatan & 33,99 & 29 & Jawa Barat & 22,82 \\
13 & Sulawesi Tengah & 33,84 & 30 & Papua Barat & 21,78 \\
14 & DI Yogyakarta & 32,22 & 31 & Maluku Utara & 19,47 \\
15 & Maluku & 32,08 & 32 & DKI Jakarta & 19,23 \\
16 & Kalimantan Barat & 31,18 & 33 & Kalimantan Utara & 16,39 \\
17 & Lampung & 31,15 & 34 & Riau & 13,21 \\
\hline
\end{tabular}

Sumber: Direktorat Jenderal Bina Keuangan Daerah Kementrian Dalam Negeri 2016

Persoalan rendahnya penyerapan anggaran pada awal tahun menurut kementrian keuangan disebabkan oleh pertama, adanya ketakutan dari aparatur di berbagai organisasi pemerintahan terkait dengan pengelolaan keuangan. Kedua, sejumlah institusi pemerintah tidak mempunyai konsep perencanaan pengelolaan anggaran yang benar-benar matang. Ketiga, kurangnya kompetensi aparatur pengelola keuanganmengenai sistem pembelanjaanserta mekanisme pertanggungjawabannya (Akbarwati, www.selasar.com). Faktor geografis dan kondisi alam serta lemahnya perencanaan, dan juga sistem tender/pengadaan barang dan jasa yang memakan waktu lama juga merupakan faktor lain yang menyebabkan terlambatnya penyerapan anggaran diawal tahun (Manafe: 2015). Fenomena ini terjadi hampir di seluruh daerah otonom,salah satunya adalah Kabupaten Timor Tengah Utara. Khusus belanja modal pada triwulan satu penyerapan anggaran hanya mencapai 2.923.116 milyar rupiah dari target 22.572.326 milyar rupiah atau 12,95 
persen dari target 25 persen dan pada triwulan dua tidak mengalami peningkatan atau hanya sebesar 14.161 .103 atau hanya 33,54 persen dari seharusnya 50 persen. Rincian target dan realisasi anggaran belanja modal Kabupaten Timor Tengah Utara termuat dalam Tabel 1.2.

\section{Tabel. 1.2.}

Rincian Penyerapan Target dan Realisasi Belanja Modal Kabupaten Timor Tengah Utara Triwulan I dan II Tahun 2015 (Ribuan Rupiah)

\begin{tabular}{lcccccc}
\hline & \multicolumn{5}{c}{ Serapan Anggaran Belanja Modal } \\
Jenis Belanja & \multicolumn{5}{c}{ Triwulan I } & \multicolumn{3}{c}{ Triwulan II } & \\
& Target & Realisasi & $\%$ & Target & Realisasi & $\%$ \\
\hline Belanja & 2 & 3 & 4 & & 5 & 6 \\
Langsung & 97.956 .124 & 16.192 .147 & 16.53 & 179.720 .101 & 58.462 .948 & 32.53 \\
Belanja Modal & 22.572 .326 & 2.923 .116 & 12.95 & 42.221 .536 & 14.161 .103 & 33.54 \\
\hline
\end{tabular}

Sumber: Survei Triwulanan Kegiatan Usaha Keuangan Badan Pusat Statistik 2015

Penelitian sebelumnya menunjukkan adanya inkonsistensi variabel kompetensi misalnya oleh Wardhana (2015) dengan hasil penelitiannya bahwa kompetensi berpengaruh positif terhadap akuntabilitas kinerja pemerintah sebaliknya, hasil penelitiannya Purtanto (2015) yaitutinggi rendahnya tingkat kompetensi SDM tidak memengaruhi kinerja penyerapan anggaran. Penelitian oleh Syarifudin (2014) juga terbukti kompetensi SDM tidak mampu meningkatkan kinerja dan kualitas laporan keuangan yang dihasilkan oleh pemerintah daerah. Sama halnya halnya untuk variabel motivasi juga terjadi inkonsistensi seperti hasil penelitiannya Puspasari (2014) dimanakinerja pegawai tidak dipengaruhi oleh tingginya motivasi individu. Kemudianjuga hasil penelitiannya Lubis (2008) serta Dhermawan, dkk (2012) bahwa 
tinggi rendahnya motivasi tidak memengaruhi kualitas dan kinerja individu atau karyawan.

Ketidakkonsistenan penelitian sebelumnya ini, mendorong peneliti untuk meneliti kembali variabel kompetensi dan motivasi dengan menambahkan variabel komitmen organisasi sebagai variabel pemoderasi. Mengindentifikasi variabel lain sebagai pemoderasi atau pemediasi merupakan salah satu cara untuk merekonsiliasi adanya ketidakkonsistenan penelitian sebelumnya (Murray 1990). Telaah penelitian telah membuktikan faktor kondisional seperti kultur, organisasional, interpersonal, dan individual bisa menjadi variabel pemoderasi maupun mediasi (Brownell, 1982). Berdasarkan telaah penelitian ini maka peneliti memilih menggunakan komitmen organisasi individu sebagai variabel pemoderasi, alasan menggunakan variabel komitmen organisasi disebabkan karena semakin kompeten seseorang, namun tanpa dilandasi oleh komitmen yang kuat bisa berakibat pada menurunnya produktivitas kinerja.Kepercayaan dan kesediaan individu dalam menerima dan melaksanakan tujuan organisasi merupakan bagian penting dari sikap atau komitmen organisasi seorang individu terhadap organisasinya (Mathis, 2001). Sebuah organisasi akanmenjadi lebih baik apabila individu yang ada dalam organisasi tersebut mempunyai komitmen yang tinggi yang ditunjukkan dengan kepedulian akan nasib organisasi.

Penelitian ini menjadi penting mengingat Kabupaten Timor Tengah Utara merupakankabupaten yang tertinggal, dimana salah satu indikator penetapannya sebagai daerah tertinggal adalah minimnya sarana prasarana (Peraturan Presiden 
Nomor 131 Tahun 2015). Pengeluaran untuk belanja sarana prasarana merupakan salah satu akun belanja modal yang telah ditetapkan dalam perencanaanoleh Pemerintah Kabupaten Timor Tengah Utara dan DPRD namun penyerapannya masih selalu tidak mencapai target perencanaan. Sehingga diharapkan pemerintah daerah Timor Tengah Utara dapat menjadikan penelitian ini sebagai rujukan dan masukan untuk lebih meningkatkan upaya penyerapan anggaran belanja modal demi percepatan pembangunan di daerah ini.

Berdasarkan isu dan fenomena di atas, disusunlah pertanyaan penelitian yaitu: Apakah kompetensi dan motivasi pejabat pengelola keuangan berpengaruh positif pada penyerapan anggaran belanja modal pemerintah daerah Kabupaten Timor Tengah Utara? Selain itu Apakah komitmen organisasi memperkuat pengaruh kompetensi dan motivasi pejabat pengelola keuangan pada penyerapan anggaran belanja modal pemerintah daerah Kabupaten Timor Tengah Utara? Adapun tujuan penelitian yaitu untuk membuktikan secara empiris kompetensi dan motivasi pejabat pengelola keuangan berpengaruh positif pada penyerapan anggaran belanja modal pemerintah daerah Kabupaten Timor Tengah Utara dan juga untuk memberikan bukti empiris komitmen organisasi memperkuat pengaruh kompetensi dan motivasi pejabat pengelola keuangan pada penyerapan anggaran belanja modal pemerintah daerah Kabupaten TTU.

Manfaat teoretis dari penelitian ini yaitu pengembangan teori keagenan (Jensen dan Meckling 1976), teori hirarki kebutuhan Maslow dan teori hygiene motivator Herzberg, dalam hubungan variabel kompetensi, motivasi dan komitmen organisasi 
pada kinerja penyerapan anggaran belanja modal. Sedangkan manfaat praktisnya adalah Pemerintah Kabupaten Timor Tengah Utara dapat menjadikan hasil penelitian ini sebagai rujukan untuk bisa mengevaluasi kinerja pejabat yang mengelola anggaran belanja modal di seluruh instansi di Kabupaten TTU, sehingga dapat meningkatkan kinerja pejabat pengelola keuangannya guna mencapai tingkat penyerapan anggaran belanja modal secara cepat dan berkualitas.

\section{LANDASAN TEORETIS}

Kedudukan principal atau pemilik dan agen yang diwakili oleh manager dalam menjalankan perusahaan berakibat munculnya permasalahan agensi karena adanya usaha memaksimalisasikan fungsi utilitas masing-masing pihak (Jensen and Meckling 1976). Ketidakseimbangan atau asimetri informasi dimana pemilik sebagai pengguna informasi memiliki lebih sedikit informasi dibanding dengan manager ataupun manajemen sebagai penyedia informasi. Dalam teori agensiprincipal membuat suatu kontrak, dengan agent dengan tujuan agar agen bekerja seperti yang diinginkan oleh principal (Lupia \& McCubbins: 2000). Pekerjaan yang dilakukan oleh agen akanberjalan sesuai dengan yang diinginkan oleh prinsipal apabila agen mempunyai kompetensi yang cukup sesuai dengan bidang tugas dan pekerjaan yang diberikan oleh prinsipal. Sebaliknya prinsipal akan memberikan atau mengeluarkan sejumlah biaya yang dinamakan agency cost dalam rangka mengawasi dan meningkatkan kinerja dari agen. Hubungan perusahaan dan karyawan di sektor privat 
oleh para ekonom di analisis dalam struktur prinsipal dan agen (Faria and Silva, 2013). Hubungan principal dan agenyang dianalisis di sektor publik terjadi dalam hal pelimpahan kewenangan khususnya di bidang perencanaan dan pembelanjaan keuangan atau anggaran (Latifah, 2010; Abdullah, 2012). Dalam struktur hubungan principal dan agen, pihak principalakan mengontrak agenuntuk mengerjakan pekerjaan sesuai tujuan dari principal (Jensen and Meckling, 1976).

Prakteknya hubungan antara principal dan agen di organisasi sektor publik dalam hal penganggaran sektor publik terdiri dari hubungan antara kepala daerah sebagai agen (bupati/walikota/gubernur) dan rakyat, sebagai prinsipal (UUNo 32 tahun 2004). Dengan memilih kepala daerah secara langsung, rakyat sebagai prinsipal telah mengontrak dan memberikan wewenang untuk bentindak atas nama rakyat kepada agen dalam hal ini bupati/walikota atau gubernur untuk mengelola sumber daya yang ada di daerah.

Hubungan kepala daerah sebagai prinsipal dan kepala OPD sebagai pengguna anggaran, pejabat pembuat komitmen dan kepala tata usaha sebagai agen di atur dalam PERMENDAGRI Nomor 13 Tahun 2006, dimana kedudukan kepala OPD dan pejabat penatausahaan keuangan daerah atau PPKD sebagai wakil dari bupati sebagai pengelola keuangan daerah. Bupati wajib melakukan kontrol melalui suatu sistem yang dikenal dengan sistem pengendalian intern agar anggaran yang ada dalam APBD dilaksanakan sesuai dengan target yang telah ditetapkan. Para pejabat pengelola keuangan dalam hal ini pengguna anggaran, kepala tata usaha, dan pejabat 
Egidius Imanuel Laka, I Made Sukartha, dan Dewa Gede Wirama. Pengaruh Kompetensi .......

pembuat komitmen berkewajiban untuk melaksanakan semua tugas yang telah dilimpahkan kepada mereka.

Hubungan antara Bupati dengan pengguna anggaran, dimana yang berperan sebagai prinsipal adalah bupati sebagai pejabat yang memiliki otoritas untuk menggunakan anggaran dan kepala organisasi perangkat daerah adalah agen yang menjalan program yang telah disepakati dan direncanakan bersama, merupakan hubungan konstruk dari pengembangan teori agensi dalam penelitian ini. Bupati sebagai prinsipal harus menempatkan setiap pejabat sesuai dengan asas-asas yang telah ditetapkan oleh undang-undang. Apabila ini terpenuhi maka para pemimpin (OPD) diharapkan mampu bekerja sesuai dengan apa yang diinginkan oleh bupati sebagai prinsipal (Undang-undang nomor 5 tahun 2014).

Mardiasmo (2009:14) mendefinisi anggaran (budget) sektor publik merupakan perencanaan pengeluaran keuangan untuk membiayai sejumlah kegiatan di daerah tersebut dan juga merupakan sumber pendapatan yang ditargetkan untuk membiayai kegiatan-kegiatan tersebut dalam periode waktu satu tahun. Sedangkan penerimaan dan pengeluaran adalah siklus atau mata rantai keuangan dalam periode tahunan yang merupakan hasil kesepakatan antara eksekutif dalam hal ini Bupati sebagai agen dan legislatif atau DPRD sebagai prinsipal. Anggaran yang telah disetujui oleh DPRD harus di gunakan secara tepat dan cepat mengacu pada peraturan yang telah ditetapkan. Peraturan menteri keuangan (PMK) nomor 101/PMK.02/2011 tentang maksud daripengeluaran untuk pengadaan barang modal, menyatakan bahwa yang dimaksud dengan belanja modal adalah pengadaan sejumlah barang yang 
mengakibatkan adanya penambahan volume dan kuantitas kekayaan yang berusia lebih dari satu siklus akuntansi, antara lainpengeluaran untuk pemeliharaan dengan tujuan maintanance, dan peningkatan atau up grade dari barang tersebut. Tanah, bangunan dan gedung, irigasi, jalan, peralatan dan mesin, merupakan jenis-jenis pengeluaran yang termasuk dalam kategori belanja modal.Selain itu ada juga pembelian atau penyewaan maupun kontrak,pengadaanbarang kesenian, barangbarang peninggalan sejarahuntuk museum, pembelian tanaman ataupun hewan, serta karya-karya tulis ilmiah berupa jurnal maupun publikasi buku.

Kemampuan seseorang dalam menyelesaikan pekerjaan dikenal dengan kompetensi. Kemampuan tersebut dibedakan menjadi kemampuan intelektual dan kemampuan fisik (Robbins, 2008:38). Sedangkan menurut Palan (2007) kompetensi merupakan karakteristik dasar seorang individu dalam memenuhi kriteria untuk menduduki sebuah jabatan.

Komitmen organisasi adalah ikatan emosional yang kuat dari karyawan pada nilai-nilai dasar organisasi dalam kedudukannya dalam organisasi tersebut, dalam rangka bekerja mencapai tujuan organisasi tempat ia bekerja (Durkin, 1999:127). Robbins (2008) menyatakan bahwa sikap senang atau nyaman dari seorang pekerja di tempatnya bekerja itulah yang disebut dengan komitmen organisasi. Menurut Curtisa et al. (2001) aspek-aspek dalam komitmen organisasi tercermin melalui pertama, anggota organisasi bersedia melaksanakan apa yang menjaditujuan dari organisasi. Aspek yang kedua adalah dedikasi untuk organisasi serta aspek loyalitas pada organisasi. Sedangkan Allen and Meyer (1993) menyatakan unsur-unsur komitmen 
organisasi antara lain yaitu, adanya keterikatan secara emosional antara karyawan dan organisasi, loyalitas individu atau karyawan untuk tetap berada di organisasi serta tanggung jawab moril untuk tetap menjadi bagian dari organisasi.

Kebutuhan manusia terbagi dalam beberapa kategori antara lain kebutuhan akan makanan, kebutuhan akan pakaian dan perumahan serta kebutuhan jasmani lainnya yang dikategorikan sebagai kebutuhan fisiologis, selain itu ada juga kebutuhan kasih sayang, perasaan memiliki, penerimaan yang baik, serta adanya pengakuan atau yang disebut dengan kebutuhan sosial. Dalam bersosialisasi inilah manusia membutuhkan pengakuan terhadap dirinya seperti harga diri, otonomi, dan prestasi serta, pengakuan dan perhatian kepada dirinya (Maslow, 2003).

Orang dalam melaksanakan pekerjaannya sering dipengaruhi oleh pemenuhan akan kebutuhannya. Ada dua hal yang mendasari hal ini yaitu factor pemenuhan kesejahteraan fisik dan yang kedua yaitu faktor kebutuhan psikologis seseorang yaitu perasaan puas dalam melakukan pekerjaan (Herzberg, 1966).

\section{Hipotesis Penelitian}

Teori keagenan menjelaskan bahwa agen dalam melakukan tugasnya harus sejalan atau sesuai dengan apa yang diinginkan oleh prinsipal. Untuk dapat melaksanakan tugas yang dibebankan oleh prinsipal maka seorang agen tentu harus selalu meningkatkan kompetensi yang dimilikinya karena dengan peningkatan kompetensi maka akan meningkatkan pula kinerjanya. Peningkatan kompetensi akan dapat meningkatkan kinerja pegawai. Kemampuan yang berasal dari karakter bawaan 
yang dimiliki seorang individu merupakan salah satu syarat yang di pakai organisasi untuk menempatkannya dalam suatu jabatan dalam rangka mencapai tujuan dari organisasi tersebut (Spencer and Spencer, 1993). Penelitian sebelumnya oleh Wardhana (2015) menyatakan bahwa kompetensi berpengaruh positif terhadap kinerja, kemudian Ridani (2015) juga menyatakan kompetensi sumber daya manusia berpengaruh positif terhadap penyerapan anggaran belanja daerah. Berdasarkan uraian dan penjelasan diatas, hipotesis pertama atau $\mathrm{H}_{1}$ dapat disusun seperti demikian:

$\mathrm{H}_{1}$ : Kompetensi pejabat pengelola keuangan berpengaruh positif pada penyerapan anggaran belanja modal

Robbins (2015: 117) menyebutkan bahwa motivasi terjadi akibat berubahnya energi dalam bentuk perasaan atau tekad untuk menggapai suatu tujuan. Selain itu motif juga diartikan sebagai adanya upaya dari pihak lain untuk mendorong seorang individu dalam rangka mencapai suatu tujuan tertentu(Sardiman, 2011: 73). Dengan demikian motif juga merupakan daya dorong dari suatu pihak kepada pihak lain dengan maksud agar pihak yang menerima dorongan dan daya gerak itu dapat melakukan sesuatu yang terbaik demi pencapaian suatu tujuan bersama.

Santoso (2011) menyatakan bahwa kualitas kinerja dipengaruhi oleh adanya motivasi dari individu, demikian juga hasil penelitian yang lain juga menyatakan bahwa kinerja pegawai ditentukan oleh adanya motivasi dari pegawai itu sendiri (Puspasari, 2014). Berdasarkan definisi dan penjelasanyang diuraikan di atas, maka formula hipotesis kedua penelitian ini adalah: 
$\mathrm{H}_{2}$ : Motivasi pejabat pengelola keuangan berpengaruh positif pada penyerapan anggaran belanja modal.

Robins (2008:108) menyatakan bahwa perasaan suka atau tidak suka maupun kenyamanan bekerja dalam suatu organisasi adalah indikator adanya komitmen organisasi seorang individu. Indikator lainnya adalah adanya penerimaan individu akan tujuan dan nilai organisasi. Ketika seorang karyawan merasa harus berbuat sesuatu untuk mencapai tujuan dari organisasi tempat dia bekerja maka hal ini akan membuat karyawan tersebut akan bertahan dan merasa nyaman untuk tetap berada dalam organisasi tersebut. Penelitianya Wardhana (2014) membuktikan semakin tinggi komitmen seorang individu pada organisasi tempat dia bekerja maka semakin memperkuat pengaruh kompetensi pada kinerja penyusun akuntabilitas kinerja instansi pemerintah. Begitu juga Sukmaantari dan Wirasedana (2015) yang menyatakan bahwa komitmen organisasi yang kuat atau tinggi maka kinerja manajerial cenderung meningkat. Beberapa hasil penelitian sebelumnya dari variabel komitmen organisasi oleh peneliti terdahulu menjadi dasar untuk peneliti menyusun hipotesis ketiga dan keempat antara lain:

$\mathrm{H}_{3}$ : Pengaruh kompetensi pejabat pegelola keuangan pada penyerapan anggaran modal diperkuat oleh komitmen organisasi

$\mathrm{H}_{4}$ : Komitmen organisasi memperkuat pengaruh motivasi pejabat pegelola keuangan pada penyerapan anggaran modal

\section{METODOLOGI}


Kabupaten Timor Tengah Utara, Provinsi Nusa Tenggara Timur merupakan lokasi atau objek penelitian, dengan sampel adalah Organisasi Perangkat Daerah (OPD) sebagai pengelola anggaran belanja modal. Penelitian ini dilakukan di tahun 2016.Jawaban responden berupa angka dalam kuesioner merupakan data kuantitatif yang digunakan dalam penelitian ini yaitu berupa angka atau jawaban responden yang diwakilioleh angka (Sugiyono, 2014: 114). Kedua adalah data yang berupa kalimat maupun angka dan skema serta gambar yang disebut dengan data kualitatif (Sugiyono, 2014: 113). Penelitian ini menggunakan daftar nama-nama satuan kerja perangkat daerah di Kabupaten Timor Tengah Utara dan juga penjelasan variabel anggaran belanja modal, kompetensi, motivasi dan komitmen orgaisasi sebagai data kualitatif.

Seluruh pejabat pengelola keuangan di pemerintah Kabupaten TTU yang berjumlah enam belas dinas, sepuluh badan dan lima kantor merupakan populasi dengan sampel sebanyak 93 orang yang terdiri dari Kuasa Pengguna Anggaran (KPA) Kepala Tata Usaha (KTU), Pejabat Pembuat Komitmen (PPK), pada masingmasing Organisasi Perangkat Daerah. Kompetensi dan motivasi pejabat pengelola keuangan merupakan variabel yang menyebabkan munculnya perubahan (exsogenvariable)sedangkan penyerapan anggaran merupakan (endogen variable), dengan komitmen organisasi sebagai pemoderasi. Knowledge skill dan attitude adalah indikator kompetensi yang dituangkan dalam pernyataan kuesioner untuk diukur. Kuesioner yang dikembangkan oleh Evicahyani (2014), yang terdiri dari 11 pernyataan merupakan rujukan kuesioner yang digunakan dalam penelitian ini. 
Egidius Imanuel Laka, I Made Sukartha, dan Dewa Gede Wirama. Pengaruh Kompetensi .......

Sedangkan indikator untuk mengukur motivasi ada dua yaitu indikatorpersonaldan organisasional. Kuesioner motivasi dikembangkan dari Ramdan (2012) yang terdiri dari 11 pernyataan.

Continuance commitmen,cohesion commitment, dan control commitment, merupakan indikator yang digunakan sebagai instrumen dalam mengukur komitmen organisasi dimana terdiri dari 11 pernyataan yang dikembangkan oleh Puspitawati (2012). Variabel penyerapan anggaran diukur dengan tiga indikator yaitu persentasi penyerapan anggaran, revisi dan kesesuaian mata anggaran dalam Daftar Isian Pelaksanaan Anggaran (DIPA) yang dijabarkan dalam 11 pernyataan yang dikembangkan dari Juliani (2013).

HASIL DAN PEMBAHASAN

Tabel 5.1. Penyebaran dan Pengemblian Kuesioner

\begin{tabular}{|c|c|c|}
\hline Keterangan & Jumlah & Prosentase \\
\hline Pengguna Anggaran & 31 & 33,3 \\
\hline Sekretaris/ Kepala Tata Usaha & 31 & 33,3 \\
\hline Pejabat Pembuat Komitmen & 31 & 33,3 \\
\hline Jumlah kuesioner yang disebar & 93 & 100 \\
\hline Kuesioner yang kembali & 87 & 93 \\
\hline Kuesioner yang tidak kembali & 6 & 6 \\
\hline Kuesioner yang tidak dapat diolah & 3 & 3 \\
\hline Kuesioner yang diolah & 84 & 90 \\
\hline
\end{tabular}

Sumber: Data diolah 2017

Kuesioner yang disebar total berjumlah 93 dari 31 OPD, dengan demikian masing-masing tiga responden untuk setiap OPD, yaitu satu kepala OPD, satu sekretaris atau kepala tata usaha dan satu pejabat pembuat komitmen. Dari 93 responden sebagai sampel ternyata yang dapat diolah hanya 84 kuesioner. Sebanyak 
71 persen atau 60 orang responden dari total responden berpendidikan sarjana diikuti dengan responden yang berpendidikan pasca sarjana atau strata 2 dengan jumlah 19 responden atau 23 persen dari total responden dan hanya 4 orang responden yang berpendidikan non sarjana. Hal ini menunjukkan bahwa para responden yang ditempatkan sebagai pengelola keuangan cenderung memiliki tingkat pendidikan yang tinggi. Responden cenderung berpengalaman sebagai pejabat pengelola keuangan hal ini ditunjukkan dari prosentase masa kerja diatas 10 tahun yang mencapai 57 persen, diikuti oleh masa kerja responden antara 4-5 tahun sebanyak 19 orang atau 23 persen dan 1-4 tahun sebanyak 19 orang atau 16 persen dari total responden.

Nilai koefisien korelasi (r) untuk semua variabel berada diatas angka 0,3dan dengan signifikansi dibawah 0,05, artinya instrumen yang digunakan untuk mengukur variabel kompetensi, motivasi, komitmen organisasi dan penyerapan anggaran belanja modal memenuhi syarat validitas. Nilaiseluruh instrumen variabel melebihi angka 0,70 , artinya instrumen yang digunakan memenuhi syarat reliabilitas.

Uji normalitas dengan nilai Asymp. Sig. 0,955 lebih besar 0,05 menunjukkan data yg dipakai berdistribusi normal.Angka tolerance untuk masing-masing variabel independen dibawah 10 yaitu 0,990 dan nilai VIFdi atas 0,1 yaitu 1,010 membuktikan bahwa model regresi bebas multikolinearitas.

Hasil uji Glejser digunakan menunjukkan bahwa variabel terikat yang bebas heteroskedastisitas, dimana nilai variabel kompetensi adalah 0,179 dan motivasi 
adalah 0,817 yang keduanya melebihi dari tingkat signifikansi yang ditentukan yaitu 5 persen.

Kemampuan kompetensi dan motivasi dalam menjelaskan variasi perubahan penyerapan anggaran belanja modal hanya mencapai 12,2 persen sedangkan sisanya 87,9 persen dijelaskan oleh faktor lain selain kompetensi, motivasi dan komitmen organisasi.Terlihat darinilai $\mathrm{R}$ Square $\left(\mathrm{R}^{2}\right)$ sebesar 0,122 persen. Signifikansi 0,000 lebih besar dari a 5 persen dengan nilai $\mathrm{F}_{\text {hitung }}$ sebesar 5,622 menunjukkan bahwa model penelitian layak digunakan dalam membuktikan hipotesis penelitian yang dibangun. Pengaruh langsung masing-masing variabel independen pada variabel dependen yaitu hipotesis satu dan dua dapat dijelaskan antara lain, pertama, nilai $\alpha$ atau konstanta sebesar positif 4,499 dengan tingkat signifikansi sebesar 0,671, bermakna apabila variabel kompetensi dan motivasi tidak ada maka penyerapan anggaran modal cenderung tetap. Kedua, koefisien regresi variabel $\mathrm{X}_{1}$ yaitu kompetensi bernilai positif 0,285 dengan nilai signifikansi 0,026 artinya apabila ada peningkatan kompetensi dari pejabat pengelola keuangan maka kinerja penyerapan anggaran belanja modal akan cenderung meningkat dengan asumsi bahwa variabel lainnya dianggap konstan atau tetap. Ketiga, nilai variabel motivasi dalam persamaan diatas adalah positif 0,365 dengan tingkat signifikansi 0,028 berarti bahwa apabila motivasi dari masing-masing pejabat pengelola keuangan meningkat sebesar satu satuan maka kinerja penyerapan anggaran modal cenderung meningkat.

Interaksi antara komitmen organisasi dengan kompetensi dan motivasi melalui uji hipotesis regresi moderasi dapat dijelaskan sebagai berikut : Pertama, nilai 
adjusted $\mathrm{R}^{2}$ sebesar 0,138 yang artinya bahwa kemampuan kompetensi dan motivasi dalam menjelaskan variasi perubahan penyerapan anggaran belanja modal yang dimoderasi oleh komitmen organisasi meningkat menjadi 13,8 persen dari sebelumnya 12,2 persen, sedangkan sisanya 86,2 persen dijelaskan oleh faktor lain diluar model penelitian ini. Hal ini menunjukkan bahwa setelah dimasukkan variabel moderasi komitmen nilai adjusted $\mathrm{R}^{2}$ mengalami peningkatan artinya bahwa kemampuan variabel kompetensi dan motivasi dalam menjelaskan perubahan variasi variabel penyerapan anggaran mengalami peningkatan setelah dimasukkan variabel moderasi. Kedua, model yang digunakan dalam penelitian ini telah memenuhi syarat kelayakan dibuktikan dengan nilai $\mathrm{F}$ sebesar 3,659 yang signifikanyaitu 0,005 atau lebih kecil dari 0,05. Ketiga, hasil interaksi antara variabel moderasi komitmen organisasi dengan variabel bebas kompetensi dan motivasi dapat diketahui dari hasil uji signifikansi t. Penjelasannya adalah sebagai berikut: pertama, konstanta yang bernilai positif 68,66 dengan tingkat signifikansi sebesar 0,127 dapat dimaknai bahwa apabila kompetensi, motivasi dan komitmen organisasi pejabat pengelola keuangan pada OPD di Kabupaten Timor Tengah Utara adalah tetap, maka kinerja penyerapan anggaran belanja modal cenderung tetap atau stagnan. Kedua, koefisien regresi moderasi $\mathrm{X}_{1} * \mathrm{X}_{3}$ bernilai positif 0,000 dengan tingkat signifikansi sebesar 0,724 dapat dimaknai bahwa hasil interaksi antara komitmen organisasi dan kompetensi dari pejabat pengelola keuangan di masing-masing OPD di Kabupaten Timor Tengah Utara menunjukkan bahwa komitmen organisasi tidak memperkuat pengaruh kompetensi terhadap penyerapan anggaran belanja modal. Ketiga, koefisien moderasi 
$2\left(\mathrm{X}_{2} * \mathrm{X}_{3}\right)$ bernilai negatif 0,483 dengan signifikansi 0,039 dapat diinterpretasikan bahwa apabila terjadi interaksi antara komitmen organisasi dan motivasi pada pejabat pengelola keuangan maka kinerja penyerapan anggaran belanja modal cenderung menurun. Ini artinya bahwa komitmen organisasi juga tidak memperkuat motivasi dalam mempengaruhi kinerja pejabat pengelola keuangan dalam penyerapan anggaran belanja modal.

\section{a. Pengaruh Kompetensi pada penyerapan anggaran belanja Modal}

Kemampuan individu untuk menyelesaikan berbagai tugas dalam pekerjaannya merupakan faktor penting dalam pencapaian tujuan sebuah organisai. Kemampuan atau kapasitas individu inilah yang dikenal dengan kompetensi (Robbins, 2008:38). Semakin tinggi kompetensi yang dimiliki seseorang cenderung meningkatkan produktivitas kinerjanya. Pengujian hipotesistelah membuktikan, semakin tinggi kompetensi pejabat pengelola keuangan di masing-masing OPD cenderung meningkatkan kinerja penyerapan anggaran di OPD tersebut. Kompetensi atau kemampuan dapat ditingkatkan dengan cara mengikuti pendidikan, pelatihan dan juga adanya pengalaman dalam bidang pekerjaannya (Widodo, 2001). Semakin tinggi kompetensi yang dimiliki oleh pelaksana anggaran di suatu organisasi, diharapkan kinerja penyerapan anggarannya semakin berkualitas dan tepat waktu.

Pejabat pengelola keuangan pada OPD-OPD di Kabupaten Timor Tengah Utara cenderung mempunyai kemampuan dan pengalaman dalam hal mengelola anggaran belanja modal, hal ini dibuktikan dengan hasil uji statistik desktiptif dimana indikator kemampuan (ability) yang dituangkan dalam pernyataan penelitian $\mathrm{X}_{1 \cdot 1}$ 
sampai $\mathrm{X}_{1 \cdot 3}$ dengan isi pernyataannya tentang pengetahuan, pemahaman, dan pengalaman tentang mekanisme belanja modal, memiliki frekuensi dan prosentasi yang tinggi. Indikator keterampilan (skill) juga menunjukkan hasil yang hampir sama dengan indikator pengetahuan dimana prosentase responden untuk pernyataan penelitian untuk indikator ini yang juga tinggi.

Hasil statistik deskripsi untuk variabel kompetensi juga menunjukkan bahwa semua jawaban responden berkategori baik, karena berada pada angka 3,40-4,20. Hasil uji hipotesis dalam penelitian ini sama dengan penelitiannya Wardhana (2015) yang menyatakan bahwa kompetensi berpengaruh pada kinerja pegawai, demikian juga dengan hasil penelitiannya Dewi (2016) yang membuktikan kapasitas sumber daya manusia memiliki pengaruh positif terhadap penerapan sistem informasi pengelolaan keuangan daerah.

\section{b. Pengaruh motivasi pada penyerapan anggaran belanja modal}

Hasil pengujian menunjukkan bahwa hipotesis diterima. Artinya bahwa peningkatan motivasi dalam bekerja dari para pejabat pengelola keuangan pada masing-masing OPD cenderung meningkatkan kinerja penyerapan anggaran belanja modal. Uji hipotesis kedua ini sama denganpenelitian dari Santoso (2011) dengan hasil penelitian bahwa kualitas anggaran dipengaruhi oleh motivasi.Demikian juga hasil penelitian dari Puspasari (2014) membuktikan bahwa motivasi berpengaruh positif pada kinerja individu pegawai.

Berdasarkan hasil statistik deskriptif menunjukkan bahwa rata-rata jawaban responden terhadap item pernyataan variabel motivasi adalah baik, merujuk pada 
angka rata-rata yang berada pada 3,40-4,20. Selain itu Hasil uji statistik deskriptif juga memberikan informasi yang menunjukkan bahwa para pejabat pengelola keuangan pada OPD-OPD di Kabupaten Timor tengah Utara memiliki motivasi yang tinggi untuk bekerja dalam tugasnya sebagai pengelola keuangan hal ini ditunjukkan dengan frekuensi dan prosentasi jawaban terhadap pernyataan penelitian yang diberikan, misalnya untuk indikator kebutuhan (needs) pernyataan $\mathrm{X}_{2 \cdot 1}$ dengan isi pernyataan " saya merasa bahwa kebutuhan dasar seperti makan secara wajar sudah terpenuhi” jawaban responden untuk setuju dan sangat setuju mencapai angka 85,8 persen. Begitu juga indikator organisasional khusus untuk pernyataan penelitian dengan isi pernyataan "saya merasa senang pengabdian saya selama bekerja di instansi ini diakui oleh atasan”. Hal ini menunjukkan bahwa motivasi pejabat pengelola keuangan OPD-OPD yang ada di Kabupaten Timor Tengah Utara dalam menjalankan fungsinya sebagai pengelola keuangan cenderung baik karena merasa bahwa kebutuhannya baik itu secara individual maupun organisasional cenderung terpenuhi.

\section{c. Komitmen organisasi memoderasi kompetensi pada penyerapan anggaran belanja modal}

Hasil uji moderate regression analisys (MRA) yaitu interaksi antara kompetensi dan komitmen organisasi menunjukkan nilai sig koefisien regresi menunjukkan anggak 0,982 yang berada di atas 0,05 bermakna pengaruh kompetensi terhadap penyerapan anggaran belanja modal tidak diperkuat oleh komitmen organisasi. 
Komitmen organisasi yang tidak memperkuat pengaruh kompetensi pada kinerja pejabat pengelola keuangan dalam rangka realisasi penyerapan anggaran berdasarkan hasil penelitian ini disebabkan oleh loyalitas dan rasa nyaman bekerja pada organisasi saat ini, dibuktikan dengan rata-rata jawaban responden khususnya untuk pernyataan loyalitas dan kebanggaan, berada pada kategori cukup baik. Rendahnya nilai rata-rata jawaban responden untuk item-item pernyataan tersebut menunjukkan bahwa keinginan pindah dari organisasinya saat ini sangat tinggi. Sikap loyalitas yang rendah terhadap organisasi tempat bekerja bisa berakibat terhadap menurunnya kinerja.

Hasil ini sama dengan penelitiannya Rudhianto (2010) dengan hasil penelitiannya bahwa komitmen organisasi tidak memoderasi partisipasi anggaran dan kinerja.

\section{d. Komitmen organisasi memoderasi motivasi pada penyerapan anggaran belanja modal}

Hasil uji hipotesis empat $\left(\mathrm{H}_{4}\right)$ menunjukkan bahwa koefisien regresi hasil interaksi antara motivasi dan komitmen organisasi $\left(\mathrm{X}_{1} \mathrm{X}_{3}\right)$ adalah bernilai negatif 0,0483 dengan nilai sig. $=0,039$. Dengan demikian pengaruh motivasi pada kinerja penyerapan anggaran belanja modal para pejabat pengelola keuangan di pemerintah daerah Kabupaten Timor Tengah Utara tidak diperkuat oleh komitmen organisasi. Dengan demikian hipotesis keempat $\left(\mathrm{H}_{4}\right)$ ditolak, artinya komitmen organisasi juga tidak memperkuat pengaruh motivasi kerja pada pejabat pengelola keuangan di OPDOPD yang ada di Kabupaten Timor Tengah Utara. Komitmen organisasi tidak 
memperkuat pengaruh kompetensi disebabkan karena sebagian besar pejabat pengelola keuangan sudah merasa jenuh berada di instansinya masing-masing hal ini dapat dilihat berdasarkan hasil jawaban dari responden terhadap item, pernyataan variabel komitmen organisasi tentang loyalitas berada di suatu instansi adalah rendah dibandingkan dengan jawaban dari pernyataan-pernyataan yang lain, hal ini artinya bahwa para pejabat pengelola keuangan merasa jenuh bekerja di organisasi atau OPD saat ini. Rasa jenuh akan rutinitas menyebabkan kinerja menurun. Hasil uji hipotesis empat $\left(\mathrm{H}_{4}\right)$ ini sama denganpenelitiannya Setyaningrum dan Murtini (2014) dimana dapat membuktikan komitmen organisasi tidak berpengaruh pada perilaku disfungsional audit. Hal ini disebabkan karena mayoritas auditor yang menjadi responden dalam penelitian ini rata-rata sudah berpengalaman atau bekerja diatas empat tahun. Auditor yang sudah berpengalaman cenderung bekerja santai dan apa adanya, tidak seperti auditor yang belum berpengalaman yang cenderung bekerja dengan giat dan penuh idealisme. Dalam penelitian ini responden telah bekerja diatas 5 tahun mencapai 23 persen dan 10 tahun keatas mencapai 57 persen.

\section{SIMPULAN, SARAN}

Adapun simpulan yang dapat diambil dari hasil uji hipotesis penelitian ini yaitu:

Kompetensi pejabat pengelola keuangan pada OPD di Kabupaten TTU berpengaruh positif pada penyerapan anggaran belanja modal, dengan demikian makapeningkatan kompetensi dari para pejabat pengelola anggaran maka kinerja penyerapan anggaran cenderung meningkat. Motivasi pejabat pengelola keuangan pada OPD di Kabupaten TTU berpengaruh positif pada penyerapan anggaran belanja 
modal, hal ini berarti bahwa semakin tinggi motivasi dari para pejabat pengelola keuangan maka kinerja penyerapan anggaran belanja modal cenderung meningkat. Pengaruh kompetensi pejabat pengelola keuangan pada OPD di Kabupaten TTU dalam penyerapan anggaran belanja modal tidak diperkuat oleh komitmen organisasi. Komitmen organisasi tidak memperkuat pengaruh motivasi pejabat pengelola keuangan pada OPD di Kabupaten TTU dalam penyerapan anggaran belanja modal.

Merujuk kepada pernyataan penelitian khususnya pada pemenuhan kebutuhan dasar dan jaminan hari tua yang nilai rata-ratanya lebih rendah dari pernyataan lain maka kepada pemerintah kabupaten Timor Tengah Utara disarankan dapat memperhatikan peningkatan pemberian insentif dalam rangka memotivasi pejabat pengelola keuangan untuk meningkatkan produktivitasnya. Pemerintah daerah Kabupaten Timor Tengah Utara juga disarankan untuk memperhatikan masa kerja seorang pejabat di suatu OPD, hal ini karena apabila seorang pejabat terlalu lama berada atau menduduki suatu posisi di suatu instansi akan menyebabkan adanya perasaan jenuh. Perasaan jenuh dapat menyebabkan loyalitas kepada organisasi tempatnya bekerja menjadi menurun. Perasaan jenuh dan rendahnya loyalitas akan berakibat pada menurunnya kinerja seseorang. Selain itu itu disarankan kepada pemerintah daerah untuk lebih meningkatkan lagi kualitas proses perencanaan dan percepatan revisi DIPA disetiap tahun anggaran. Hal ini disebabkan karena jadwal pelaksanaan kegiatan dan perencanaan dalam DIPA pemerintah daerah Kabupaten Timor tengah Utara belum sepenuhnya sesuai dengan kebutuhan dan jadwal yang telah ditetapkan. 
Egidius Imanuel Laka, I Made Sukartha, dan Dewa Gede Wirama. Pengaruh Kompetensi .......

Hasil analisis regresi moderasi menunjukkan bahwa adjusted $\mathrm{R}^{2}$ sebesar 0,138 yang bermakna bahwa hanya 13 persen variabel bebas dapat menjelaskan variasi perubahan variabel terikat. Karena itu saran peneliti untuk peneliti selanjutnya adalah dapat menambahkan variabel lain yaitu kompensasi, kualitas penyusunan anggaran, dan komitmen pimpinan untuk diteliti lebih dalam lagi. 


\section{REFERENSI}

Abbdullah, S. 2012. "Perilaku Oportunistik Legislatif dan Faktor - Faktor Yang Mempengaruhinya: Bukti Empiris dari Penganggaran Pemerintah Daerah di Indonesia". disertasi. Yogyakarta: UGM.

Akbarwati,Https://www.selasar.com/politik/pentingnya-penyerapan-anggaran/diakses Juni 2016

Allen, N. and Meyer, J.P. (1993). Organizational Socialization Tactics: A longitudinal analysis of links to newcomerse commitment and role orientation. Academy of Management Journal, Vol 33 (4) pp: 847- 858.

Brownel, P. and Mcaines, M. 1986. Budgetary Participation, Motivation and Managerial Performance. The Accounting Review. Vol 61 (4) pp: 587-600

Curtisa, Susan, and Dennis Wright. 2001. Retaining Employees-The Fast Track to Commitment. Management Research News. Vol 24 (8/9) pp: 59-64

Dewi, S.A.N, Trisna. 2016. Dukungan Manajemen Puncak Sebagai Pemoderasi Pengaruh Kapasitas Sumber Daya Manusia dan Teknologi Pada Implementasi Sistem Informasi Pengelolaan Keuangan Daerah (SIPKD) Di Pemkot Dps. "(tesis)": Denpasar

Dhermawan, Ngurah A.A, Sudibya I.G, I, Mudiartha Utama. 2012. Pengaruh Motivasi, Lingkungan Kerja, Kompetensi dan Kompensasi terhadap Kepuasan Kerja dan Kinerja Karyawan di Lingkungan Kantor Dinas Pekerjaan Umum

Durkin, M. 1999. Employee Commitment in Retail Banking: Identifying and Exploring Hidden Dangers, International Journal of Bank Marketing.Vol 17 (3) pp: $124-137$

Evicahyani, S. Intan. 2014. "Analisis faktor-faktor yang memengaruhi kualitas Laporan Keuangan Pemerintah Daerah Kabupaten Tabanan" (tesis)": Denpasar: Universitas Udayana

Faria, J.A., dan Silva, S.M.G. 2013 The Effects of Information Asymmetry on Budget Slack: An Experimental Research. African Journal of Business Management vol 7(13),pp.1079-1086.

Juliani Dian .2013. "pengaruh komitmen manajemen, pengetahuan tentang peraturan, lingkungan birokrasi, dan kontrol output dari penyerapan anggaran yang berkaitan dengan pengadaan barang / jasa. di Pemerintah Daerah Istimewa Yogyakarta" (tesis). Yogyakarta: UGM 
Herzberg, F. I . 1966.Resurrecting the Motivation-Hygiene Theory: Herzberg and the Positive Psychology Movement.Human Resource Development Review Vol 6 (4) pp: 377-393

Jensen, M. C and Meckling, W.H. 1976. Theory of the Firm: Managerial Behavior, Agency Costs and Ownership Structure. Journal of Financial Economics. Vol 3 (4) pp: $305-360$

Latifah, N.P. 2010. Adakah Perilaku Oportunistik dalam Aplikasi Agency Theory di Sektor Publik. Fokus Ekonomi Vol. 5 (2) pp: 85-94.

Lubis, Khairul. 2008. "Pengaruh Kinerja dan Motivasi Terhadap Kinerja Karyawan PT Perkebunan Nusantara IV”.(tesis). Medan: USU

Lupia and McCubbins, M. 2000. "Representation or Abdication? How Citizens Use Institutions to Help Delegation Succeed." European Journal of Political Research. Vol 37 (3) pp: 291 - 307.

Manafe, A.2015. "Analisis Faktor - Fakktor Yang Mempengaruhi Penyerapan Anggaran Belanja Modal Di kabupaten Rote Ndao. (tesis). Yogyakarta: UGM

Mardiasmo. 2009. Akuntansi Sektor Publik. Yogyakarta: Andi

Maslow, Abraham. 2003. Motivasi dan Kepribadian. Jakarta: Midas Grafindo

Mathis, Robert L dan John H. Jackson. 2006. Manajemen Sumber Daya Manusia Edisi Pertama. Jakarta: Salemba Empat

Murray, D. 1990. The Performance Effect of Participative Budgeting: An Integration of Intervening and Moderating Variables. Behaviour Research In Accounting. Vol 2 (2) pp: 104-121.

Palan, R. 2007. Competency Management, Teknik Mengimplementasikan Manajemen SDM Berbasis Kompetensi Untuk Meningkatkan Daya Saing Organisasi, Cetakan Pertama, Edisi Bahasa Indonesia, Jakarta: PPM Anggota IKAP

Purtanto. 2015. "Faktor-faktor yang Mempengaruhi Penyerapan Anggaran Belanja Pemerintah Daerah: Proses Pengadaan Barang dan Jasa (studi pada pegawai bersertifikat pengadaan barang dan jasa di pemerintah kota Tegal" (tesis). Surakarta: UNS

Peraturan Pemerintah Republik Indonesia Nomor 53 Tahun 2010 tentang Penyerapan Anggaran. 
Tahun 2015-2019

Nomor 131 Tahun 2015 Tentang Penetapan Daerah Tertinggal

Peraturan Menteri Keuangan (PMK) nomor 101/PMK.02/2011 Tentang Klasifikasi Anggaran

Puspasari, M.A.W. 2014. "Pengaruh Motivasi Dan Budaya Organisasi Terhadap Komitmen Organisasi Dan Kinerja Karyawan” (tesis). Yogyakarta: Atmajaya

Undang-undang Nomor 5 Tahun 2014 Tentang Aparatur Sipil Negara (ASN) Nomor 32 Tahun 2005 Tentang Otonomi Daerah.

Pemerintah Pusat Dan daerah

Ramdan, Zulfitri. 2012. "Pengaruh Kompetensi Komite Audit Terhadap Penyisihan Penghapusan Aktiva Produktif” (tesis). Jakarta: Universitas Indonesia

Ridani, M. Arsyad .2015. “Analisis Penyerapan Anggaran Belanja Daerah Kabupaten Bulungan, Metoda penelitian yang digunakan adalah metoda kuantitatif dengan analisis faktor eksploratif (Exploratory Factor Analysis-EFA) dan metode kualitatif dengan analisis deskriptif kualitatif" (tesis): Yogyakarta: UGM

Rudhianto, Hermawan. 2010. "Pengaruh Komitmen Organisasi dan Gaya kepemimpinan Terhadap Hubungan Antara Partisipasi Anggaran dan Kinerja" (tesis): Universitas Sebelas Maret: Surakarta

Robbins, S.P dan Timothy A. Judge. (2015). Perilaku Organisasi, Edisi 16. Jakarta: Salemba Empat.

Robbins, P. Stephen \& Judge Timothy A. 2008. Perilaku Organisasi. Edisi 12. Jiid 1. Alih Bahasa Diana Angelica dkk. Jakarta: Salemba Empat.

Santoso B, Djoko. 2011. "Pengaruh Kompetensi dan Motivasi Auditor Pada Kualitas Audit (Studi Empiris Pada Kantor Akuntan Publik di Denpasar dan Badung)" (tesis). Denpasar: Univesitas Udayana

Sardiman, A.M. 2011. Interaksi dan Motivasi Belajar Mengajar. Jakarta: Rajawali Pers.

Spencer, L.M. dan Spencer, S.M. 1993. Competence Work: Model for Superior Performance: Jhon Willey and Sons Inc.

Sukmantari, D.A.Made dan Wirasedana, I.W.Pradnyantha. 2015. Pengaruh Partisipasi Penganggaran dan Komitmen Organisasi Pada Kinerja Manajerial Dengan Kepuasan Kerja sebagai Variabel Intervening.E-Jurnal Akuntansi Universitas Udayana.Vol 10 (1) pp: 261 
Egidius Imanuel Laka, I Made Sukartha, dan Dewa Gede Wirama. Pengaruh Kompetensi ......

'Sugiyono. 2014. Metode Penelitian Bisnis Pendekatan Kuantitatif, Kualitatif $R$ dan $D$ Cetakan 20Bandung: Alfabeta.

Syarifudin, A. 2014.Pengaruh Kompetensi SDM dan Peran Audit Intern terhadap Kualitas Laporan Keuangan Pemerintah Daerah dengan Variabel Intervening Sistem Pengendalian Internal Pemerintah (studi empiris pada Pemkab Kebumen) Jurnal Fokus Bisnis, Vol 14 (2) pp: 26-42

Wardhana, A.R. Gede. 2015. "Pengaruh Kompetensi Terhadap Akuntabilitas Kinerja Instansi Pemerintah Dengan Komitmen Organisasi Sebagai Pemoderasi” (tesis). Denpasar: Universitas Udayana

Widodo, J. 2001. Good Governance Telaah Dari Dimensi Akuntabilitas, Kontrol Birokrasi Pada Era Desentralisasi dan Otonomi Daerah. Insan Cendekia: Surabaya 